\title{
Spiritual Expressions' Prediction of Mindfulness: The Case of Prospective Teachers
}

\author{
S. Barbaros Yalçin \\ Ahmet Keleşoğlu Faculty of Education, Necmettin Erbakan University, Turkey
}

Copyright $\odot 2018$ by authors, all rights reserved. Authors agree that this article remains permanently open access under the terms of the Creative Commons Attribution License 4.0 International License

\begin{abstract}
The purpose of this research is to determine whether prospective teachers' spiritual expressions have predicted their mindfulness. The research was conducted in relational screening model. The study group consisted of 411 students $(81.2 \%)$ females and $94(18.6 \%)$ males, totally 505 undergraduate students who are studying in the last year and who participated in teaching practice. For data collection procedure, the Mindful Awareness Scale, developed by Brown and Ryan [9] was used. Turkish validity and reliability of the scale was studied by Özyeşil, Arslan, Kesici and Deniz [8] and the Spiritual Expression Scale (SES), developed by Macdonald [26]. This scale was studied in Turkish with Turkish validity and reliability by Şahin and Baloğlu [27]. The results indicate that there is a positive meaningful relationship at nominal level between the mindfulness and the spiritual expression orientation with the religiosity sub-dimension and the spiritual cognitive orientation subscale; a negative meaningful relationship at nominal level between experiential phenomenological sub-dimensions; a positive meaningful relationship at moderate level between the existential well-being sub-dimensions. However, there is no meaningful relationship between mindfulness and paranormal beliefs sub-dimensions. As a result, it is seen that existential well-being sub-dimension of spiritual expression inventory predicts mindfulness.
\end{abstract}

Keywords Mindfulness, Prediction, Prospective Teachers, Spiritual Expressions

\section{Introduction}

It is a generally accepted approach that human beings have always been in search for development throughout their life. Their awareness about their own lives and their clearness in this quest is not always easy. It is not a situation in which the persons themselves, the world of objects, the meaning of other people and their ideas and acceptance can be obtained easily. In this process, the search for meaning in life comes out as a necessity which includes spirituality. The ability of people to think is developed by the need to acquire new and specific information from experiences they have gained over their lifetime, the ability to come up with the problems they have experienced, and the means of their life interpretation. Indeed, the human spirit rises up while overcoming challenges and obstacles [1]. The science of psychology considers the existential needs that make up the human body while examining basic concepts [2]. Although no one is certain, all people expect to find some meaning in life [3]. While the meaning of the life was an important concept especially in psychology in the past, today it has been extensively explored in all areas of psychology.

The most profound and most universal human need is the fundamental motivation of the quest for meaning [4]. It is also basically intended to serve self-transcendence and a greater purpose [5]. One of the basic tasks in our lives is finding a solid goal to support life. We often have a sense of discovering meaning and then we feel that the meaning we think we are discovering already exists somewhere [6]. Positive psychology in this sense presents the concept of being aware of us. Consciously our own awareness can help us to discover the search for meaning in our life.

It is a fact that life brings out different needs to meet in order to survive for people each day. In this process, the ability to express oneself and the style of expression increases in importance. For this reason, people have difficulties in terms of the meaning of life in order to have many means to facilitate life [7]. In order to overcome this tension, spiritual significance has gained a keen interest in being aware of the situation as well as being able to express this meaning. It can be said that the change and speed in modern time nowadays is not equal to the change in the mindfulness of people living in this change [8]. A high level of awareness in this process can be cited as the factors that affect the quest for meaning in life after the meaning in spirituality and then the potential to express the person related to spirituality.

The concept of mindfulness can be expressed as a high awareness situation, which has increased its popularity 
recently, but it has its bases in eastern Buddhist tradition [8]. If we see the definition of mindfulness from another point of view, it can be shortly defined that the individual is in a state of caution and is aware of the moment that he or she has lived, that is, now and here. It can be said that what is important here is that when he focuses on himself now the person is aware of the moment, and giving attention himself without judging him or herself [9]. As mentioned before, the root of mindfulness is based on eastern philosophy, tradition and belief. However, in the related literature, the concept of mindfulness has become a popular topic in western societies and in the scientific world [10].

There are a number of research findings that show that mindfulness is associated with many negative variables $[11,12,13]$. In his study [13], mindfulness was associated with anxiety, depression, and stress in the negative direction. Similarly, Xu et al. [11] report that mindfulness and posttraumatic stress disorder symptoms are associated with depression and avoidance negatively. In support of these findings, another meta-analysis study suggests that mindfulness-based stress programs might help individuals deal with their clinical and non-clinical problems [14]. In addition, the mindfulness is found in the continuity of spirituality. It is also stated that the increase in the perception of psychological health is highly correlated [15].

When it's thought that the Buddhist belief relying on the concept of mindfulness may be associated with spirituality, the increase in the mindfulness will also members of religious and may cause an increase in the spiritual sense and said it can increase the level of awareness on this issue [24]. In the Eastern cultures and in many different beliefs, meditation which is generally considered to be a type of prayer is an important part of spiritual aspiration. This form sometimes turns out to be a secular relaxation exercise out of a religious worship. Thus, scientists are subjected to investigate the effects of meditation on the health of soul and body.

As long as the human being has recognized the existence of the God especially in the historical process, they sometimes pray to God to express their wishes, sometimes their complaints, sometimes gratitude, sometimes regret and repentance, and sometimes only to share their feelings. As Horozcu (2010) mentions, prayer is believed to be a psychologically important means of outsourcing [25]. Having the ability to express him spiritually can have an endless feeling of relief. Being able to express oneself can contribute to making the life of the person meaningful. In particular, it can be said that there is a concept that can make the life of the individual meaningful in existential terms, and to remove the obstacles in front of gratitude now and here.

In a related study it is stated that mindfulness-based stress program increases mindfulness and spirituality. It has been mentioned that there is a meaningful relationship between increasing mindfulness and increased spirituality. However, it is also stated that increasing mindfulness and spirituality in the same study are associated with a decrease in psychological distress and medical symptoms of individuals [15]. It has been stated that, following the mindfulness-based stress program, increased experience of spirituality can lead individuals to have a better mental health [16].

Gutmann states that "Life is the synthesis of personal and universal components of spirituality-related values, entity and essence, freedom and discipline" [17]. Frankl regarded spirituality as the aspect that separates human beings from other beings and constructed it as a search for meaning, creation of meaning, orientation toward value and importance, and making life worth living, even in pain [5].

Spirituality has been regarded as a taboo within the psychology science for many years because of its limitless boundaries [6] and it has been marginalized $[18,19]$. However, MacDonald [23] states that spirituality in empirical data can not only be studied in a meaningful way, but also has a high level of preference for the individual.

Although consensus on the definition of spirituality has not been reached [20], it is discussed in the context of religion psychology [21,22] and also it has been addressed in broader context [23]. Zinnbauer et al. [20] show that religiosity and spirituality are different concepts but they are not completely independent of the two concepts. According to Averill [29], spiritual experiences can be assessed in two different ways: secular and religious. Seligman [28] deals with spirituality in a non-religious context and uses it as transcendence and conceptualizes it as emotional power that reaches out to the more permanent (other people, the future, the holy / divine or the universe) outside and beyond the person himself/herself. Spirituality and transcendence are coded by Seligman [28] as one of the six virtues that can attain common traditions or beliefs of thousands of years. Peterson [30] considered spirituality one of the components of the transcendence that he described as "powers that helped establish and connect with the wider universe".

In short, meaning and spirituality of life are regarded as determining variables in terms of positive psychological properties. It is important to investigate how different sub-dimensions of spirituality are perceived in different cultures, whether universal spirituality can be discussed. It is seen that the subdivisions of different disciplines and psychology define these concepts according to their theoretical orientations. For this reason, it is a problem of this research to reveal if prospective teachers are able to predict mindfulness of their spiritual expressions.

\section{Material and Method}

\section{Research Model}

In this study, the type of relational screening, the genre of the general screening model, is employed. The relational 
screening model is a research approach aimed at determining whether there is coexistence between more than one variable and, if there is change, the degree of change.

\section{Study Group}

The study group of this research consists of students who are studying at Necmettin Erbakan University, Ahmet Keleşoğlu Faculty of Education. The sample of the research is the prospective teachers who are studying in different departments and participating in the teaching practice in the last grade of the university. Of the prospective teachers who participated in the teaching practice, $411(81.2 \%)$ female and 94 (18.6\%) participated in the study with a total of 505 prospective teachers. Participants were given an informed consent form at the beginning of study. The participants are in different parts of the education faculty, and the participants voluntarily participated in the research.

\section{Data Collection Tools}

\section{The Mindful Awareness Scale}

The Turkish validity and reliability study of the scale, developed by Brown and Ryan [9], was conducted by Ozyesil, Arslan, Kesici and Deniz [8]. Mindful Awareness Scale has a total of 15 items. The Mindful Awareness Scale has a one-factor structure and gives a single total score. The high scores on the scale indicate that mindfulness is high. MAS is a Likert-type scale with 6 degrees (almost always, often, sometimes, rarely, very rarely, almost never). Both explanatory and confirmatory factor analysis were performed for the validity of the MAS structure. In the explanatory factor analysis, the MAS showed a one-factor structure. Factor load values range from .27 to .78 . According to the confirmatory factor analysis results, the compliance indices confirm that MAS has a one-factor structure. The internal consistency coefficient of your scale is .82 . The item correlations obtained from the scale range from .25 to .72 . The test-repeat reliability of the MAS was evaluated by a four-week intervention, with a correlation of .81 between the two treatments. For MAS's criterion-related validity; Five Major Personality Traits, Continuous Emotional State Scale, Mindfulness Unawareness Scale and Self Consciousness Scale were used and significant relationships were determined between them.

As a result of item total correlation, by Ozyesil, Arslan, Kesici and Deniz [8] for MAS, a relation of over .40 for all items of the scale has emerged. The factor loadings of the MAS for each item range from .48 to .81 . The Cronbach Alpha internal consistency coefficient of the scale was .80 and the test-retest correlation was calculated as .86 . Cronbach's alpha internal consistency coefficient, calculated according to item analysis for reliability of the scale, is .80 and test-retest correlation is .86 .

\section{The Spiritual Expressions Scale (SES)}

The original form of the SES developed by Macdonald [26] is a 98 -item likert type scale with 5 sub-dimensions including cognitive orientation, experiential/ phenomenological dimension, existential well-being, paranormal beliefs and religiosity. Factor analysis revealed that these five factorial structures accounted for $46.7 \%$ of the total variance. The Cronbach alpha coefficients for scale subscales ranged from .85 to .97 [23].

Because of the high number of items in the SES, especially due to difficulty for adults and elderly individuals, the scale was revised to form a short form [26]. In this short form, the five dimensions in the original form are preserved and six items in each sub-dimension. In this way, the short form of the scale is composed of 5 items of Likert type with a total of 30 items. The Cronbach alpha internal consistency coefficients of the revised scale subscales ranged from .80 to .89 [26].

The first attempt to adapt the SES revision form to Turkish was made by Şahin and Baloğlu [27]. However, in the confirmatory factor analysis performed, the values of acceptable adaptive well-being were not achieved. In this study, the revised short form of the SES was revised and adapted to Turkish.

\section{Data Analysis}

In this study, Pearson Moments Multiplication Correlation Coefficient technique was used to determine the relationship between mindfulness of prospective teachers and the various dimensions of spirituality. The stepwise technique of multiple regression analysis was used to determine how much the prospective teachers predicted the variance of mindfulness levels of spiritual expression levels.

\section{Findings}

The findings are the results of statistical analyzes of data collected in accordance with the purpose of the research.

In Table 1, the relationship between mindfulness and the various dimensions of spirituality was investigated. For this purpose, the correlation coefficients between the total score of the CAS and the total score of the SES and subscale scores were calculated.

Table 1. The Relationship between Mindfulness and Spiritual Expression

\begin{tabular}{|c|c|}
\hline & mindfulness \\
\hline Spirituality Cognitive Orientation &, $123^{* *}$ \\
\hline Experiential Phenomenological Dimension &,$- 105^{*}$ \\
\hline Existential Well-being &, $457^{* *}$ \\
\hline Paranormal beliefs &,- 080 \\
\hline Piety &, $124^{* *}$ \\
\hline
\end{tabular}

$* * \mathrm{p}<.01$

$* \mathrm{p}<.05$ 
When Table 1 was examined, there was a low level of positive correlation between mindfulness and the spiritual cognitive orientation sub-dimension of the spiritual expression inventory $(\mathrm{r}=, 123, \mathrm{p}<.01)$. There was a significant low correlation between mindfulness and the experiential phenomenological sub-dimension of the spiritual expression inventory $(r=-105, p<.05)$ on the negative side.

There was a moderately significant positive correlation between mindfulness and the existential well-being sub-dimension of the spiritual expression inventory $(\mathrm{r}=$, $457, \mathrm{p}<.01$ ). There was no significant relationship between mindfulness and the paranormal beliefs sub-dimension of the spiritual expression inventory $(\mathrm{r}=-, 080, \mathrm{p}>.05)$. A low level of positive correlation was found between mindfulness and the religiousness sub-dimension of the spiritual expression inventory $(\mathrm{r}=, 124, \mathrm{p}<.01)$.

When Table 2 is examined, it is seen that the existential well-being sub-dimension of the spiritual expression inventory predicts mindfulness $(\mathrm{p}<.001)$. The existential well-being sub-dimension of the spiritual expression inventory accounts for $20.4 \%$ of the total variance for mindfulness.

Table 2. Mindfulness Inventory of the Spiritual Expression A: Existential Well-being

\begin{tabular}{|c|c|c|c|c|c|}
\hline Model & $\mathrm{B}$ & $\mathrm{SA}$ & $\beta$ & $\mathrm{t}$ & $\mathrm{p}$ \\
\hline Constant & 42.260 & 1,534 & & 27.554 & 001 \\
\hline Existential Well-being & 1,067 &, 094 &, 453 & 11,307 & 001 \\
\hline $\mathrm{R}=, \mathrm{R}^{2}=453, \mathrm{R}^{2} 205(\mathrm{Adj})=204 \mathrm{~F}=127.842 \mathrm{p}=001$ \\
\hline
\end{tabular}

\section{Discussion and Conclusions}

When the literature of the relevant field was examined, it was not found that there were works of spiritual expression and mindfulness. For this reason, while discussing the research, the relationship between the sub-dimension of the spiritual expression scale and the mindfulness scale will be tried on a theoretical basis on the concepts of spiritual expressions and mindfulness. The findings will be interpreted in a flexible way because the concept of mindfulness is a concept that carries both spiritual elements and cognitive elements [8]. It is important to note that the purpose of this research is based on the assumption whether there is relationship between spiritual expressions of consciousness and mindfulness or not, and how much the variance of mindfulness of spiritual expressions predicts. The discussion part will be made in two parts. In the first part, the relation between the spiritual expressions of prospective teachers and their mindfulness will be discussed. In the second part, findings about the extent of the variance of mindfulness of the prospective teachers' spiritual expressions will be discussed.

As the scores of the cognitive orientation subscale of prospective teachers' moral expression scale increase, they increase at mindfulness levels, because; prospective teachers can cognitively seek evidence while expressing their spiritual world. Evidence in their minds increases the levels of mindfulness. With this increase, awareness levels may increase when expressing spiritual issues about living together. When they are aware of ascension, they feel more comfortable, and therefore tend to develop mindfulness levels. At the same time, when prospective teachers do not show any cognitive orientation, they may have difficulty understanding and interpreting the events happening in their surroundings. It may be because these difficulties cannot re-frame events and find no evidence when expressing spiritual orientation as the basis for their lives.

Mindfulness scores are also increasing as the scores of the religiosity subscale of the prospective teachers' spiritual expression scale increase because religiosity can be focused on the present moment, and it is possible to live the present moment to a certain criterion. At the present time, religion brings in evidence of the mental conventions and rules that religion has found. Because the individual who establishes a cognitive balance between the increase of religiosity and mindfulness can express himself better spiritually. The increase in the level of religiousness of the religious person can be achieved by the reduction of contradictions in the mind and the increased awareness of what they do.

Mindfulness levels are also increasing as the scores of existential well-being subscale of the prospective teachers' spiritual expression inventory increase because the individual seeks a meaning of life. It is in a constant quest to find meaning. Uncertainty may emerge in the mind as the individual sees meaning for its existence. It may be necessary to raise mindfulness in order to be able to overcome these uncertainties because the individual must first convince himself to make sense of life. And then it has to internalize the meaning it has developed in life. This internalization process can also take place with understanding now and here. Now and here, the concept can be made in the individual as long as it makes sense to both life and feelings [4].

As the scores of experiential phenomenological subscale of prospective teachers' spiritual expression level increase, mindfulness levels decrease. If individuals are subjective when interpreting the world they live in, i.e. they cannot interpret their lives according to personal prejudices, personal criteria and values; they cannot exhibit an objective life of events in their surroundings. For this reason, the level of mindfulness may be reduced if they are not objective. It's necessary to objectively approach the criteria for evaluating the time and events that individuals have in order to increase the level of mindfulness.

There was no significant relationship between mindfulness and paranormal beliefs sub-dimension of the spiritual expression inventory of prospective teachers. This result may mean that there is no relationship between paranormal beliefs and mindfulness that are beyond and 
beyond the physical laws and natural forces and which are not explained to them because mindfulness focuses on the now and conscious. On the other hand, paranormal beliefs focus on beliefs beyond natural forces.

The second part, in which research findings are discussed, can be explained by the fact that individuals are now and here to try to live the moment if they explain $20.4 \%$ of the variance of the mindfulness of the subcategory of spiritual expressions and the subcategory of mindfulness. Individuals may need to make sense of the life they live in for their memories. When creating this meaning, it may be necessary to make a meaning away from cognitive distortions and contradictions. In short, it is necessary for the individual to have a meaning that is consistent, understandable and responsive to the impasse in the individual's mind.

In conclusion, significant relationships between prospective teachers' spiritual expressions and mindfulness levels can be explained by the fact that they try to understand the lives of prospective teachers, their emotions and the moment they are in at the moment, and their focus on mental evidence and their search for consistency. For the further research, studies can be made between the spiritual expression scale and other cognitive variables (cognitive distortions, early incoherent schemes) as seen in research findings.

\section{REFERENCES}

[1] Deurzen E.V. \& Adams, M. (2015). Varoluşçu Danışmanlıkta ve Psikoterapide Beceriler. (Skills in Existential Counselling \& Psychoterap) (Çev. Ed.: Ferhat Jak İçöz).Pan Yayıncılık.

[2] Batthyany, A., \& Russo-Netzer, P. (2014). Psychologies of meaning. In Meaning in positive and existential psychology (pp. 3-22). Springer New York.

[3] Corsini, J Raymond \& Danny Wedding. 2017. Modern Psikoterapiler. (Current Psychotherapies). 2. Bask1. Kaknüs Yayınlar1.

[4] Frankl, V. E. (2017). İnsanın anlam arayışı (Çev. S. Budak). İstanbul: Okuyanus Yayınları.

[5] Wong, P. T. (2016). Meaning-seeking, self-transcendence, and well-being. In Logotherapy and existential analysis (pp. 311-322). Springer International Publishing.

[6] Emmons, R. A. (2003). Personal goals, life meaning, and virtue: Wellsprings of a positive life. Flourishing: Positive psychology and the life well-lived, 105-128.

[7] Frankl, E. V.(1999). Duyulmayan anlam çı̆̆lığı psikoterapi ve hümanizm (Çev. S. Budak). Ankara: Öteki Yayınevi.

[8] Özyeşil, Z., Arslan, C., Kesici, Ş., \& Deniz, M. E. (2011). Bilinçli Farkındalık Ölçeği'ni Türkçe'ye uyarlama çalışması. Eğitim ve Bilim 36(160), 224-235.

[9] Brown, K., \& Ryan, R.M. (2003). The benefits of being present: Mindfulness and its role in psychological well-being. Journal of Personality and Social Psychology 84(4): 822-848.

[10] Kabat-Zinn, J. (2003) Mindfulness-based interventions in context: Past, present, and future. Clinical Psychology: Science and Practice 10(2): 144-156.

[11] Xu, W., Fu, G., An, Y., Yuan, G., Ding, X., \& Zhou, Y. (2018). Mindfulness, posttraumatic stress symptoms, depression, and social functioning impairment in Chinese adolescents following a tornado: Mediation of posttraumatic cognitive change. Psychiatry Research, 259, 345-349.

[12] Hjeltnes, A., Moltu, C., Schanche, E., Jansen, Y., \& Binder, P. E. (2018). Both sides of the story: Exploring how improved and less-improved participants experience mindfulness-based stress reduction for social anxiety disorder. Psychotherapy Research, 28(1), 106- 122.

[13] Ulev, E. (2014). Üniversite öğrencilerinde bilinçli farkındalık düzeyi ile stresle başa çıkma tarzının depresyon, kayg1 ve stres belirtileriyle ilișkisi(The Relationship Between Mindfulness and Coping Styles with Depression, Anxiety and Stress Symptoms in University Students). (Yayınlanmamış Yüksek lisans tezi). Hacettepe Üniversitesi, Sosyal Bilimler Enstitüsü, Ankara.

[14] Grossman, P., Niemann, L., Schmidt, S., \& Walach, H. (2004). Mindfulness-based stress reduction and health benefits: A meta-analysis. Journal of Psychosomatic Research, 57(1), 35-43.

[15] Carmody, J., Reed, G., Kristeller, J., \& Merriam, P. (2008). Mindfulness, spirituality, and health-related symptoms. Journal of Psychosomatic Research, 64(4), 393-403.

[16] Greeson, J. M., Webber, D. M., Smoski, M. J., Brantley, J. G., Ekblad, A. G., Suarez, E. C., \& Wolever, R. Q. (2011). Changes in spirituality partly explain health-related quality of life outcomes after Mindfulness-Based Stress Reduction. Journal of Behavioral Medicine, 34(6), 508-518.

[17] Guttmann, D. (2008). Finding meaning in life, at midlife and beyond: Wisdom and spirit from logotherapy. ABC-CLIO.

[18] Emmons, R. A. (2006). Spirituality. M. Csikszentmihalyi, M., \& IS Csikszentmihalyi (Eds.), A life worth living. contributions to positive psychology, 62-81.

[19] Ellis, A. (1989). Dangers of transpersonal psychology: A reply to Ken Wilber. Journal of Counseling \& Development, 67(6), 336-337.

[20] Zinnbauer, B. J., Pargament, K. I., Cole, B., Rye, M. S., Butter, E. M., Belavich, T. G., \& Kadar, J. L. (1997). Religion and spirituality: Unfuzzying the fuzzy. Journal for the Scientific Study of Religion, 549-564

[21] Underwood, L. G. (2006). Ordinary Spiritual Experience: Qualitative research, interpretive guidelines, and population distribution for the Daily Spiritual Experience Scale. Archive for the Psychology of Religion, 28(1), 181-218.

[22] Lips-Wiersma, M. (2002). The influence of spiritual "meaning-making" on career behavior. Journal of Management Development, 21(7), 497-520.

[23] MacDonald D. A. (2000a). Spirituality: Description, 
measurement, and relation to the five factor model of personality. Journal of Personality, 68(1), 153-197.

[24] Koenig, H. G. (2004). Religion, spirituality, and medicine: research findings and implications for clinical practice. Soutlienı medical journal. 97 (12), 1194-1200.

[25] Horozcu, Ü. (2010). Tecrübi Araştırmalar Işı̆̆ında Dindarlık ve Maneviyat ile Ruhsal ve Bedensel Sağlık Arasındaki İlişki.( The Relationship Between the Religiousness \& Spirituality and Mental \& Physical Health in the Light of Empirical Researches) Milel ve Nihal inanç, kültür ve mitoloji araştırmaları dergisi. 7(1). 209-240.

[26] MacDonald, D. A. (2000b). The Expressions of Spirituality Inventory: Test development, validation and scoring information. Unpublished test manual.

[27] Şahin, R. \& Baloğlu M. (2016). Maneviyat İfadeleri
Envanteri uyarlama çalışması. (Spirituality expressions inventory adaptation work) I. Avrasya Pozitif Psikoloji Kongresi, 28-30 Nisan 2016, Üsküdar Üniversitesi, İstanbul.

[28] Seligman, M. E. (2004). Authentic happiness: Using the new positive psychology to realize your potential for lasting fulfillment. Simon and Schuster.

[29] Averill, J. R. (2002). Emotional creativity: Toward "spiritualizing the passions". In, Snyder, C. R and Lopez, S. J. (Eds.), Handbook of positive psychology, 172-185. Oxford University Press.

[30] Peterson, C (2006). The values in action (VIA) classification of strengths. M. Csikszentmihalyi, M., and IS Csikszentmihalyi (Eds.), A life worth living: Contributions to positive psychology, 29-48. 